Autor, V. A. Análise econômica do manejo de RPPN's: um estudo sobre o Ecoturismo na Fazenda Vagafogo, Pirenópolis (GO). Anais do VIII Congresso Nacional de Ecoturismo e do IV Encontro Interdisciplinar de Ecoturismo em Unidades de Conservação. Revista Brasileira de Ecoturismo, São Paulo, v.4, n.4, 2011, p. 568.

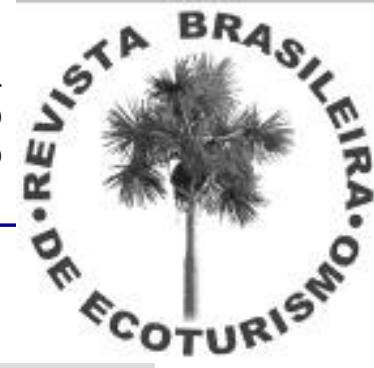

\title{
ANÁLISE ECONÔMICA DO MANEJO DE RPPN'S: UM ESTUDO SOBRE O ECOTURISMO NA FAZENDA VAGAFOGO, PIRENÓPOLIS (GO)
}

\author{
Keila Sanches*, Alvaro Nogueira de Souza*, Ana Paula Camelo* \\ *Universidade de Brasília \\ E-mails: keila.sanches@gmail.com, ansouza@unb.br, paulaflorestal@gmail.com
}

O presente estudo teve como objetivo avaliar economicamente as atividades desenvolvidas na Fazenda Vagafogo no Município de Pirenopólis/GO. As atividades analisadas foram Trilha Ecológica e Turismo de Aventura. Obteve-se informações do número de visitantes/ano, preços ao consumidor, custos da terra, custos de manutenção/investimento e custos com mão de obra. Os critérios econômicos utilizados foram Valor Presente Líquido (VPL) e Benefício Periódico Equivalente (BPE), considerando uma taxa de desconto de $8 \%$ a.a, períodos analisados entre 1996 a 2008, e entre 2005 a 2008, além de um horizonte de planejamento de 10 anos com o ano de referência 2008. Constatou-se que, no período de 1996 a 2008, a visitação ecoturística na Fazenda Vagafogo apresentou um crescimento médio de $6 \%$ a.a e a média anual de visitantes foi de 8.889. Os resultados mostraram que o uso indireto da RPPN da Fazenda Vagafogo é viável economicamente e no período de 2005 a 2008 apresentou para a atividade Turismo de Aventura um VPL de $\mathrm{R} \$ 3.536,33 /$ ha e um BPE de $R \$ 1.067,69 /$ ha.ano-1, para as atividades Turismo de Aventura + Trilha Ecológica obteve-se um VPL de $R \$ 13.290,58 /$ ha e um BPE de $\mathrm{R} \$ 4.012,70 /$ ha.ano-1. Ao longo dos 10 anos, encontrou-se para as atividades Turismo de Aventura + Trilha Ecológica um VPL de $\mathrm{R} \$ 25.552,50 /$ ha e um BPE de $\mathrm{R} \$ 3.808,08 /$ ha.ano-1. Desta forma, concluiu-se que as atividades de uso indireto na RPPN da Fazenda Vagafogo são economicamente viáveis e apresentam rentabilidade superior a de atividades convencionais para a região do cerrado no Estado de Goiás.

Palavras-chave: Pirenópolis; Fazenda Vagafogo; RPPN. 